\title{
From Global to Multi-Scalar Sovereignty: Intersectional Political Community as Resistance
}

\author{
Óscar García Agustín \\ Department of Culture and Learning, Aalborg University, Aalborg, Denmark \\ Email: oscar@hum.aau.dk
}

How to cite this paper: Agustín, Ó. G. (2021). From Global to Multi-Scalar Sovereignty: Intersectional Political Community as Resistance. Open Journal of Political Science, 11, 193-214.

https://doi.org/10.4236/ojps.2021.112013

Received: December 31, 2020

Accepted: February 5, 2021

Published: February 8, 2021

Copyright $\odot 2021$ by author(s) and Scientific Research Publishing Inc. This work is licensed under the Creative Commons Attribution International License (CC BY 4.0).

http://creativecommons.org/licenses/by/4.0/

\begin{abstract}
With the publication of Empire, Michael Hardt and Antonio Negri announced a new form of sovereignty, Empire, which implied moving from nation-state sovereignty to global sovereignty. This paper revises some of the main aspects of the theory to understand Imperial sovereignty as well as its post-territorial political community of resistance, multitude. In this critical reading of some of Hardt and Negri's concepts, sovereignty is conceived as two-sided: a conflictual relationship between the one who rules and those who are ruled. This conflictual approach implies the revitalization of popular sovereignty (as opposed to the constituted order) and of territory, albeit not limited to the nation-state. As a result, an alternative framework is offered to explain the existing forms of sovereignties consisting of three elements: multi-scalar sovereignty, interdependence and intersectional political community. This approach, rather than taking the point of view of the states, explores the forms of sovereignty promoted by social movements and civil society in general.
\end{abstract}

\section{Keywords}

Empire, Globalization, Sovereignty, Multitude, Political Community, Multi-Scale, Interdependence, Intersectionality

\section{Introduction}

When revisiting their book Empire, Michael Hardt and Antonio Negri (2019: p. 67) refuse that globalization is either dead or even in decline but rather "less easily legible". Since the processes of globalization are less legible, they claim for more attention to how global governance has been constituted in the last twenty years through the powers of nation-states and the global structures of capitalist 
production and reproduction. Their statement is in contradiction with all the analysts who mourn the decline of the liberal order and the reactionary forces that defend the return of national sovereignty, including the left wing which sees national sovereignty as the space to resist the attacks of neoliberalism, multinational corporations and global elites. Despite the defeatism of the liberalists (the end of the liberal international order) and the reaction of the nationalists (the return of national sovereignty from the right and the left), Hardt and Negri maintain a similar position to the one formulated twenty years ago: Globalization is an irreversible process and any attempt to oppose it (by claiming the return to modern sovereignty) would be wrong, regardless of reactionary or emancipatory intentions.

The conceptualization of globalization in its form of Empire already provoked a lot of criticism. Slavoj Žižek saluted the book as the "Communist Manifesto for the twenty-first century" for proving that, following Marx, capitalism digs its own grave. The deterritorialization, caused by globalization, makes it more difficult for capitalism to control all the centrifugal forces so the supposed global triumph of capitalism unveils, in reality, its vulnerability. The assumption of globalization as the only reality of both dominance and resistance was highly contested. Žižek (2001: p. 193) calls Empire pre-Marxist due to the trust in how the socio-economic process will create the space for radical measures or, in other words, that revolution will emerge out of "the inherent antagonisms of the capitalist mode of production". In this regard, the revolution claimed by the Left does not need to be planned or hoped for, given that it would have already taken place (Brennan, 2003). Besides the immanent reading of Marx to account for Empire as form of domination and counter-Empire as one of resistance, the critiques aimed at the replacement of imperialism with Empire, the total rejection of the role of states and sovereignty, and the limitations of multitude as political subject. Hardt and Negri's position has been labeled postmodern globalist ideology of post-Marxism (Browning, 2005), left-liberalism (Cremin \& Roberts, 2011), neoliberal globalization-sympathizing (Fotopoulos \& Gezerlis, 2002) or, in sharper tone, "infantile vanguardism" (Thompson, 2005). Samir Amin synthetizes some of the concerns that Empire raised within the Left by claiming that the underlying position sustained by Hardt and Negri is that there is no alternative to the current phase of capitalism: "This is the discourse of our moment of defeat, a moment that has not yet been surpassed." The only option then is to move away from such a discourse: "The renaissance of a left worthy of the name, capable of inspiring and implementing progress for the benefit of the people, requires a radical rupture with discourses of this type" (Amin, 2005: p. 12).

When moving away from state-centric visions within an International Relations perspective, there are two aspects I consider of vital importance: domination and resistance. As pointed out by David Chandler (2006), power and domination have traditionally been understood in two ways: formal empire, as denial of the right to self-government, and informal empire, as the information rela- 
tions in the socio-economic sphere of market relations. Although Empire was originally the domination of other territories, deprived of their right to sovereignty, approaches like Hardt and Negri's "have focused on empire based on the power of capital rather than formal territorial control and the denial of sovereignty" (Chandler, 2006: p. 13). Despite their inclusion of factors of political and military power, it is true that the global expansion of capital is the main factor to explain the shift towards imperial sovereignty and the emergence of multitude, particularly when Empire becomes a non-space. On the other hand, I would like to introduce the question raised by Richard K. Ashley about how to understand "community" in international political life. Ashley (1987: p. 406) reminds us that for realists what characterizes international politics is anarchy and not community. Communities are circumscribed within sovereign states and exist only at the level of national society. Thus, "there is no political community in the pluralistic world of power politics". The proposal contained in Empire challenges the distinction between national (communities and sovereign states) and international (anarchy) through a principle of decentralized power (Empire, global capital) and an emerging transnational community (a multitude, political subjectivities).

Hardt and Negri offer, in all, a new approach to globalization by opposing Empire and multitude and highlighting the decline of the state as an actor capable of controlling global processes. However, the focus on Empire as informal empire (the mechanisms of global capitalism) ignores the centrality still played by sovereignty in defining the political community and even how the loss of the control of sovereignty by the state implies that other actors promote alternative narratives of who that community is. In other words, the definition of both sovereignty and political community is at stake. Furthermore, the imprecise nature and composition of multitude makes the concept insufficient when talking about a political community. Therefore, I propose a rereading of some of the aspects of Empire (and more widely the work of Hardt and Negri) to move from the idea of global (or Imperial) sovereignty to multi-scalar sovereignty, where the global is one of the scales together with the national and the local, and from multitude to intersectional political community (as a way of overcoming a homogeneous identity or the exclusivity of the national sphere).

In the following, I will focus on Hardt and Negri's conceptualization of sovereignty (and the shift from modern to Imperial sovereignty) and multitude, as the new political community. Subsequently, I will revise those concepts in order to develop the meaning and implications of multi-scalar sovereignty and intersectional political community as alternatives.

\section{Towards Global Sovereignty}

From the beginning of their book, Hardt and Negri (2000) warn about the centrality of sovereignty to understand globalization (economic and cultural exchanges), since a new form of sovereignty has emerged: "Empire is the political subject that effectively regulates these global exchanges, the sovereign power that 
governs the world". The decline of nation-states does not imply the decline of sovereignty. Although one wonders if this new form of sovereignty is as irreversible as globalization or if relationships between novel governmentalities and claims to sovereignty are satisfactorily addressed, Hardt and Negri offer a framework to overcome the validity of modern sovereignty (nation-state sovereignty) and modern political community (the nation, the people) to grasp the challenges derived from the global world. Therefore, I present Hardt and Negri's arguments to reject the validity of modern sovereignty to account for global politics and to embrace consequently a new form of global constitution (Imperial sovereignty) and of global resistance (multitude).

\subsection{Modern Sovereignty}

Hardt and Negri's (2000: p. 74) rejection of any form of sovereignty is rooted in their understanding of modern sovereignty. The authors of Empire conceive modernity not as unitary but unfolded in two modes: Modernity as a radical revolutionary process which "declares the immanence of the new paradigm of the world and life" and defines "a tendency toward a democratic politics, posing humanity and desire at the center of history"; and modernity as a form of transcendent constituted power against immanent constituent power and of order against desire. The dichotomy of immanence and transcendence creates two ontological and incompatible ways of understanding politics. Shortly, immanence is "the idea that there are no transcendental principles or agents relevant to human life, and that whatever norms, institutions, or critiques we generate must be explicated and defended without reference to such transcendentals" (Moore, 2011: p. 3). Hardt and Negri pursue then to develop an immanence politics by recovering modernity as radical revolutionary process and opposed to any form of transcendental constituted power. The revolutionary process is incarnated by multitude, capable of using its immanent powers to construct an alternative through autonomous and nonhierarchically organized self-management (Harvey, Hardt, \& Negri, 2009). The transcendental power is, on the other hand, deployed by the modern state to dismantle the power of multitude.

Modern sovereignty represents the second mode of modernity to prevent multitude from "organizing itself spontaneously and expressing its creativity autonomously" (Hardt \& Negri, 2000: p. 83). Transcendence manifests itself through sovereignty and representation. In their explanation of how both constitute forms of command and transcendence, Hardt and Negri underpin the intertwined conceptualizations made by Hobbes on sovereignty and Rousseau on representation. Only moving from sovereignty and representation attached to this mode of sovereignty, immanence politics, as a process of liberation, would be possible.

Hobbes's idea of an absolute sovereign ruler helps to understand the formation of a transcendent political apparatus as form of mediation to eliminate the revolutionary potential of immanence. The plurality of wills is unified and represented in the will of the transcendent sovereign. Thus, the transcendence of 
the sovereign is founded on the immanent logic of human relations, but the sovereign power, through the legitimization attributed by representation, separates it from the multitude of subjects. Rousseau would make a similar point when he admits that political representation is impossible since the will cannot be represented but, in order to preserve sovereignty, it is necessary to represent the "general will" as unified and unanimous political subject (Hardt \& Negri, 2017). The representative and unified character of the general will contrasts with the plurality of the "will of all" which is not representable and consequently opposed to any form of sovereignty. Hardt and Negri conclude that despite abandoning divine notions of authority which have been secularized, modern power is still theological due to the transcendent position occupied by sovereign power above society and outside its structures (Hardt \& Negri, 2009).

The main political communities associated with modern sovereignty were the nation and the people. The nation became, indeed, the hypostasis of the general will and national sovereignty, and popular sovereignty the best way of improving modern sovereignty. Rather than being the result of sovereignty, the nation claims to precede it and to be prior to its historical development. The nation ends up becoming "the condition of possibility of all human action and social life itself" (Hardt \& Negri, 2000: p. 101). When the notion of "the people" emerged, it reinforced sovereign power due to the losing capacity of the nation as sole legitimating force. The people naturalized sovereignty, too, and complemented the nation. However, "the people" would not be the primordial basis of the nation but a product of the nation-state. The implications of this claim are enormous: The shift to a form of global sovereignty questions the usefulness of sovereignty (and representation), characteristic of the modern state, and of the people as political community, as dependent on the form of the modern state.

\subsection{Imperial Sovereignty}

As mentioned above, Empire is the sovereign power that governs the world. Far from being the end of sovereignty, Empire entails a new form of sovereignty called Imperial sovereignty where Empire is the ultimate subject of sovereignty. The hypothesis is that "sovereignty has taken a new form, composed of a series of national and supranational organisms united under a single logic of rule" (Hardt \& Negri, 2000). Antonio Negri deepens this vision when affirming that nation-states no longer mean anything because there is only one way of thinking politics: globally. Contrary to the interpretations of International Relations in terms of competing nation-states, national politics would now happen only within the globalized world. The emergence of continental maps (the United States, Europe, Russia and China) reflects a structure defined by the friction between two tectonic plates: "on one side, the real globalization that actually happened, on the other side, the political plate that is fragmented into continental dimensions" (in Shibasaki, 2019: p. 11). Thus, Empire is not a homogeneous and univocal subject, and nation-states are not in direct conflict with Empire. Mi- 
chael Hardt (undated) emphasizes that it would be wrong to think that the increasing power of globalization means decreasing power of nation-states or vice versa. Nation-states are continuously being reorganized in the form of Imperial sovereignty.

Empire can easily be defined in contrast to imperialism which is a phenomenon of modernity, characterized by the competition between states in the international arena, by means of extending the sovereignty of European nation-states beyond their own boundaries. The definition of boundaries was crucial: The territorial boundaries of the nation delimited the center of power whose rule was exerted over external territories. Empire entails the end of a territorial center of power and fixed boundaries. Empire is "a decentered and deterritorializing apparatus of rule that progressively incorporates the entire global realm within its open, expanding frontiers". Whereas modern sovereignty resides in limiting territory and policing its boundaries, imperial sovereignty is expansive and its space is always open. In short, Empire is the single sovereign power. Probably, a great part of the critique against Empire (Boron, 2005; Amin, 2005, 2014) aimed at these two points: not acknowledging the predominance of some national powers in the international field (instead of thinking in terms of friction as suggested by Negri) and refusing the existence of a new form of imperialism (instead of accepting the decentralized and deterritorializing Empire).

Nonetheless, there is no way back to nation-state sovereignty or to recover the modern critical strategy for Hardt and Negri, since the border place between inside and outside no longer exists. It is not possible to define sovereignty, as happened with modern sovereignty, through the relation of the territory and its outside. Imperial sovereignty works in a similar way to the world market which, undoing any type of divide between inside and outside, makes the entire globe its domain. Comparing with the places of modernity, constructed through the dialectical opposition between inside and outside, there is no place of power for Empire; it is everywhere and nowhere.

Empire being the single sovereign power could lead to thinking that it is uncontestable or, at least, difficult to contest. Hardt and Negri, on the contrary, celebrate the possibilities opened by Empire and consider wrong any opposition to Empire within the logics of modernity and modern state. The absence of outside strengthens the claim for immanence politics. The modern state, by deploying transcendent authority, was an obstacle to developing the immanent and democratic forces. The situation changes with Empire: Imperial sovereignty is decentralized and not organized around one central conflict but micro-conflicts and its conflicts are then everywhere. Furthermore, capitalism is now dependent on the production of communication, emotions, language and affect, expressed by the immanent forces of desire and cooperation of the multitude (what Hardt and Negri call "the common"). Despite the uncertainty about when and how, multitude becomes the political subject to shape the counter-Empire that would offer a new global alternative and a new way of living in the world. 


\subsection{Multitude}

In modernity, the multitude and the people represented two modes of modernity: the revolutionary vs. the counter-revolutionary or the immanent vs. the transcendent. From their origins, both concepts are defined by opposition. "The people" is unity, having one will, and to whom one action may be attributed. It entails identity and homogeneity through generating the divide between the inside (what the people is) and the outside (what the people is not). On the other hand, multitude is "a multiplicity, a plane of singularities, an open set of relations, which is not homogeneous or identical with itself and bears an indistinct, inclusive relation to those outside of it" (Hardt \& Negri, 2000: p. 103). The people and multitude are in conflict: The former enhances a single will and action, and the latter entails a plurality of wills and actions. State sovereignty aims to neutralize the immanent and revolutionary forces of multitude through transcendent authority and reducing the multiplicity of multitude into the unity of the people. Multitude is not reducible to sameness (as it happens with the people) since it is both multiplicity and collectivity at the same time (Ali, 2020). The challenge here is double: How to avoid that multiplicity becomes fragmentation and incoherence, and how to avoid that collectivity is shaped by a common unified identity? Hardt and Negri do not rely on identity but on what the multiplicity of subjects has in common. The new global organization in networks allows multitude to communicate, collaborate and share a common political project (Hardt \& Negri, 2004). It should not be forgotten, as Negri recalls, that the concept of multitude was born as a class concept. In the global context, the exploitation of work has expanded to the exploitation of society, including other subjects such as women, students, sexual minorities, ethnic groups, etc. Multitude pursues to cover the multiplicity of singularities that the homogenizing force attributed to "the people" by Hardt and Negri excludes.

The opposition between the people and multitude is not restricted to modernity. The same differences can be identified when talking about populism nowadays. Hardt and Negri (2017) single out a similar starting point between the work of Ernesto Laclau and their own: There is no single subject that can unify the heterogeneity of the social field. This is the only common aspect. Both projects differ in their position on immanence or transcendence. According to Hardt and Negri, Laclau applies a transcendent operation through the hegemonic formation from above consisting in reducing the plurality of social subjectivities into "the people" in antagonism with an outside (the elite, what people is not). The problem, they conclude, is that Laclau is still relying on categories of modern politics and modern sovereignty, not adequate to grasp the new form of imperial sovereignty. Multitude, on the contrary, implies the self-organization from below of the multiplicity of social subjectivities in struggle. There is no need for transcendent intervention (representation or sovereignty), and the main challenge is to organize existing struggles which already are exploiting and making visible the contradictions of global capitalism. If modern sovereignty provoked 
the exclusion of the multitude in favor of the people, Imperial sovereignty, decentered and expansive, creates the condition to liberate the productive and immanent forces of multitude. Any attempt to reclaim "the people" as political community in times of Empire is doomed to fail. Despite the difficulty of imagining how the global network of the multitude, as plurality of singularities, can speak as such (Çubukçu, 2005: p. 6), social cooperation and collective intelligence would develop a horizontal decision-making model.

\section{Critical Standpoints}

Having presented some of the most important points of Hardt and Negri's framework, I would like to introduce some critical reflections regarding their conceptualization of sovereignty and of multitude as the new political Empire. Basically, I argue that ignoring other types of sovereignty and of political communities is reducing the field of contestation and limiting the responses to and within global sovereignty, particularly when assuming the perspective of social and political struggles. The search for non-sovereign institutions, suggested by Hardt and Negri, as an option out of sovereignty, can be quite limited to articulate a political community of resistance. For this reason, I reincorporate the idea of popular sovereignty, despite its tension with the notion of the multitude, although, as I understand it, popular sovereignty cannot be attached exclusively to nation-state. This territorial perspective is also applied to the notion of post-territorial political communities in order to regain the local and national framework within a global perspective.

\subsection{The Limitation of Non-Sovereignty}

As mentioned, sovereignty has not disappeared but moved from states to Empire. Thus, sovereignty in its new form is central, but this is only true regarding the side of domination. The recognition of Imperial sovereignty does not imply that the antagonist emergent political subject (multitude) aims to become the new sovereign. Multitude, indeed, pursues to become non-sovereign. This scenario contributes to uncertainty in several aspects: How can the new form of sovereignty (more complex than modern sovereignty) be contested only by non-sovereignty (exodus)? Why is it necessary to renounce to state sovereignty when global sovereignty remains uncontested (so far only in the form of non-sovereign institutions)? And most importantly: Can sovereignty be reduced only to the field of domination? I consider it important to address these questions to deepen Hardt and Negri's idea of sovereignty as contradictory relationship as well as to rethink the role of state sovereignty and of non-sovereignty as the solution offered to combat Imperial sovereignty.

In Multitude, Hardt and Negri (2004: p. 332) warn that the realm of the political cannot be reduced to state sovereignty, given that sovereignty is a more complex concept. Sovereignty is two-sided, consisting of "a relationship between rulers and ruled, between protection and obedience, between rights and obliga- 
tions". There is no one side that is more important than the other or indispensable (either those who obey or the one who commands). Indeed, the ruled revolted and restored sovereignty when tyrants appropriated sovereignty and tried to convert it into something unilateral. The utility of violence and war is limited, and consent is also needed. In order to obtain obedience, the sovereign power must constantly negotiate the relation with the ruled. The duality of sovereignty does not only imply that sovereignty is negotiated: It is also a constant struggle. Thus, the two-sided relationship becomes both an obstacle for the sovereign power, feeling how its power is blocked or limited, and an opportunity to challenge and overthrow the sovereign power.

I consider this conception of sovereignty as two-sided essential to redefining sovereignty in times of crisis of nation-states and increasing globalization (but also processes of localization). Sovereignty is not something posed by the sovereign power, and its relational nature implies, too, that it is conflictual. The ruled do not necessarily accept a certain type of sovereignty and protests and rebels against it. At the state level, sovereignty could be understood in terms of tensions and conflicts between the ruler and the ruled, as well as at the global level, where the relations of domination and the actors (including the political community) would vary.

However, Hardt and Negri do not explore this duality of sovereignty because their goal is how to avoid the sovereignty trap and not how to understand the relations between actors in the conflictual relationship between those who command and those who are ruled. Hardt and Negri conceive that the only option to fight against the asymmetric relation of sovereignty and the position of servitude aimed at the ruled is that the ruled subtract themselves from that relationship. This move is an act of liberation and a kind of exodus. Hardt and Negri want to emphasize that such an exodus would not entail withdrawing from the struggle against the sovereign and power or giving the whole power to the sovereign. Since sovereignty is a relationship, the act of refusal is a real threat that makes sovereignty crumble. The increasing dependence of Empire on multitude makes it impossible to exclude population, as happened under modern sovereignty, and an apparent paradox emerges: Empire creates a global society that is becoming more autonomous, since the Empire relies on society. In this regard, Hardt and Negri (2004: p. 336) appreciate the potential of liberation for multitude as counter-Empire as overcoming sovereignty: "We are thus no longer bound by the old blackmail: the choice is not between sovereignty or anarchy. The power of the multitude to create social relationships in common stands between sovereignty and anarchy, and it thus presents a new possibility for politics". Consequently, in Assembly they present the creation of non-sovereign institutions as the only alternative to the new form of global sovereignty.

It is at least contradictory that Empire is a new form of global sovereignty, in the making or already existing, that can be resisted only from non-sovereign positions or exodus, or that sovereignty is two-sided unless the ruled (that is not an option for the ruler) subtract themselves from that relation. As mentioned pre- 
viously, it would be more interesting to conceive political and social struggles within the tensions and conflicts derived from the duality of sovereignty (including those of autonomy). Hardt and Negri shift focus from the passage from state to imperial sovereignty to the one from sovereignty to non-sovereignty. Whereas the struggles for or within state sovereignty did not belong to the struggles of the multitude, the movements that do not aim to achieve autonomy are not considered as part of the multitude either. Sovereignty is reduced to the place of domination rather than struggle, and any possibility of framing political and social struggles as struggles for sovereignty is eliminated.

\subsection{The Reclaiming of Popular Sovereignty?}

Hardt and Negri's reluctance towards modern sovereignty (and sovereignty in general) as field of battle remains clear in their lack of interest in exploring popular sovereignty as mode to articulate social demands (the ruled) in conflict with the sovereign power (the ruler). This antagonism would be consequent with the conflictual relationship of sovereignty as two-sided. However, Hardt and Negri refer only twice to popular sovereignty and in both cases as synonym of national sovereignty. This is not surprising when people are considered a unifying category, reducing the multiplicity of singularities of the multitude, and any form of representation is rejected for similar reasons. However, by excluding popular sovereignty, the distinction between national and popular sovereignty becomes irrelevant, and the potential of popular sovereignty to challenge the established order (in a similar manner to what Hardt and Negri do when opposing constituent and constituted power) is ignored. My intention in this section is to introduce popular sovereignty as complementary to the previous idea that sovereignty as relationship is still relevant and implies the existence of conflict between two actors that pursue prevalence or change of the existing order.

The tension between the "general will" (unified and object of sovereignty) and "will of all" (multiplicity and contrary to sovereignty) must be understood within the larger distinction reflecting the two sides of sovereignty. The very idea of "popular sovereignty" is almost irreconcilable with the one of sovereignty: The latter refers to an indivisible authority, above the law, whilst the former is about the rule by the demos (Brown, 2010). Besides the duality of sovereignty, another phenomenon must be taken into account: the "detachment of sovereignty from the nation-state" (Brown, 2010: p. 24) when emerging and consolidating other global forces. There are two conceptions of sovereignty: as disputed concept (the dual side) and as declining sovereignty (the friction between nation-states and globalization). These conceptions do not correspond exactly with the divide between internal and external sovereignty, because, if sovereignty is becoming global, the duality can also be reflected at the global level. That said, nation-state is still predominant, but not exclusive, when political and social struggles claim for popular sovereignty.

The question is whether sovereignty moving to other scales should follow by 
giving up popular sovereignty. According to Hardt and Negri, that should be the case, for two reasons: Popular sovereignty is anchored in modern sovereignty (and there is no way back in relation to that), and "the people" entails the rejection of immanence and the multiplicity of subjectivities. However, the claim for popular sovereignty is not (or, at least, not only) an attempt to return to nation-state sovereignty. Hardt and Negri make an interesting point by affirming that global capitalism (biocapitalism or cognitive capitalism) relies strongly on multitude (its creativity as source for the common), but, in their hopes for an organized multitude to come, they do not consider how neoliberalism, as current form of global capitalism, is undoing the demos and its consequences for our understanding of democracy. Wendy Brown (2015: p. 31), for instance, puts the emphasis on the ubiquitous economization of all features of life by neoliberalism. Besides the marketization of all spheres, this means that "neoliberal rationality disseminates the model of the market to all domains and activities [...] and configures human beings exhaustively as market actors, always, only, and everywhere as homo oeconomicus". Human beings are then configured as homo oeconomicus, particularly as human capital across all spheres of life. Here the dependence of capital on the forces of multitude should counter such powerful subjectivization, but it is not quite clear how. Brown's critique of Foucault for not paying attention to homo politicus could be applied to Hardt and Negri as well. Except for organizing multitude, there is a lack of attention to how to build a political alternative which does not emerge from Empire as economic system of production. In this attempt to resist the homo oeonomicus, Brown suggests to reclaim democracy. This is not possible without popular sovereignty: "Whatever popular sovereignty might mean in contemporary national and post-national politics the link between democracy and popular sovereignty is one we just can't give up" (in Celikates \& Jansen, 2012: p. 69). Despite its imprecise meaning, popular sovereignty becomes necessary to recover control by the people, equality and participation. Thus, sovereignty is not limited to the one who commands and not even to the representative system, but it is open to political and social forces.

Neoliberal rationality re-signified democracy, equality and freedom as values oriented towards the market. Popular sovereignty becomes then an anomaly, since the marketization does not apply to spaces where the people rules itself. For this reason, the claim for popular sovereignty can become a turning point to recover the meanings of equality and freedom into a democratic project. Popular sovereignty is an openness by the demos in opposition to the closure of the sovereignty by the ruler. This conceptualization of popular sovereignty can avoid the risk of sovereignty becoming the "general will" (unified, attributed by a transcendent power) instead of the "will of all" (Baiocchi, 2018). Sovereignty can easily be used to cement a partial view of the world. Baiocchi proposes that sovereignty must not be a state but a process where both the "We" and sovereignty are open to reinvention. Since sovereignty is a relationship, rather than empha- 
sizing only one side (the "We" or the sovereign), the ruler (being sovereign) and the demos ("the people") must work together: "the We placing a check on Sovereignty, while Sovereignty gives the We more meaning” (2018: 20). The importance of popular sovereignty to forge a democratic project should not be taken uncritically, and one should be cautious of the meaning that is attributed to it. Control by the people and the redefinition of the community can be strongly attached to re-territorialization of power within the limits of the nation-states by opposing globalization (Kallis, 2018). In this case, it is necessary to pay attention to the meanings given to democracy by popular sovereignty and how it is positioned in the tension between state and global sovereignty (and the resulting political community).

\subsection{The Reterritorialization of Post-Territorial Political Community}

Previously, I questioned the rejection of sovereignty and the non-sovereign option as the only one and the omission of popular sovereignty (for being part of the already overcome modern sovereignty). Now I look at the limitation of multitude as political community, called to replace territorialized political communities and to respond to Empire at the global level. After a short appreciation of multitude, I assess some of the problems derived from its condition as post-territorial political community and the need to recover the territorial perspective.

It is curious that "the people" as category can have progressive or reactionary meanings (like popular sovereignty) but multitude, as conceptualized by Hardt and Negri, is conceived only as a positive and democratic force. From a different perspective, Paolo Virno (2004: p. 17) characterizes multitude as an "amphibious" category, as Sylvère Lotringer manifests in the foreword: it "can veer toward 'opposing developments', or come to nothing, so a combat is constantly raging not with Empire, within itself'. It is also amphibious in another sense: It speaks of social production based on knowledge and language and of the crisis of the state (Virno, 2004). Multitude is presented as alternative to the form of state, but not as only positive. It is true that multitude can be solidary and cooperative (in Gago, 2006), but it is not exempt of aggressiveness or self-destructive drive. In any case, the contention of mitigation of multitude would not be solved, rather the opposite, by the state. Virno's conception of multitude offers a different understanding of multitude as ambivalent that adds internal contradictions and risks to overcome. Nonetheless, both share the idea that multitude should develop autonomous and stateless spaces. This point leads me to some considerations about the post-territorial political community.

David Chandler (2009a) addresses quite critically the possibilities of post territorial political community. He singles out that state sovereignty has been challenged from above (the biopolitical processes of production manifested in the form of Empire) and from below (the resistance to neoliberal governance by multitude). Chandler, comparing liberal cosmopolitans and radical poststructuralists, underpins three problematic issues. First, instead of demonstrating the 
existence or strength of alternative post-territorial community, the starting point is the rejection of state-based political community. Second, the political community's lack of conceptual grounding (the existence of the rights-bearing subject) as the connection between citizenship and political community is broken. Finally, the mediating links of political community are so attenuated that it is difficult to see the connection between particular individuals or struggles and the collective political subject.

It is clear that the initial conceptualization of multitude as counter-Empire generated expectations of an emerging global political subject, but it remains rather an abstract concept, or, when being concretized, it is mainly rooted in local spaces (conceived as spaces of autonomy or non-sovereignty that challenged global sovereignty). Therefore, the final pages of Empire are quite surprising because they present a global program to combat Empire. The incongruence consists in formulating the program as rights: the right to global citizenship, the right to social wage or basic income and the right to reappropriation. Due to the absence of a global subject, it is strange to attribute it rights which require to be managed and applied at the national and local levels too. Chandler (2009a: p. 60) talks about political community without political subjects, given that "the problematic question of political representation and the formal constitution of political community" is evaded. For this reason, I pointed out the contradiction derived from considering multitude as existing community (attributing it rights such as global citizenship) when the main goal is to organize existing struggles emerging from the contradictions of biocapitalism.

To solve the contradictions of post-territorial political community, Chandler highlights that political community takes a nation-state territorial form to organize itself for political representation, but this is not incompatible with post-territorial content at the ideological and political levels, as expressed by international solidarity and support. I agree with the combination of intertwined state-territorial and post-territorial connections. However, the critique of the lack of existing political community at the global level comparable with the national one should not ignore the crisis of state sovereignty and how the territorial and post-territorial connections are becoming a necessity of political subjects to face global issues. The state is still the main arena to define political community. No doubt at all. But it is also insufficient if a perspective from social and political movements is adopted. Even walling the states, as Brown indicates, is a symptom of the eroding sovereignty. The issue is rather to identify the existing struggles at different scales and to see how they contribute to forging such a political community.

Coming back to the issue of popular sovereignty, it raises the question whether political communities are restricted to nation-state. It is true that it is difficult to think of an articulation of the people beyond nation-state territory. If so, it should lead to the use of the people (as particular) and humanity (as universal). However, the dichotomy between Empire and counter-Empire can be the 
ground to imagine a kind of transnational populism. Antal Attila (2019), combining his reading of Chantal Mouffe with Hardt and Negri, suggests to understand "multitude" as empty signifier to articulate global struggles against the global elites. This idea is, of course, contrary to Hardt and Negri's immanent conception of multitude which is besides de-embedded from the sphere of social production and reproduction. However, it introduces a new perspective on how multitude can be articulated to gather social demands (and rights) at the global level.

\section{Towards Complex Sovereignty}

The shift from nation-state to global sovereignty, claimed by Hardt and Negri, is problematic in several aspects: Global sovereignty is still ongoing and difficult to detach from nation-state sovereignty (and their tensions and frictions); the redefinition of sovereignty should not lead to getting rid of it as the main alternative (through exodus or non-sovereignty); forms of sovereignty like popular sovereignty refer to the two sides of sovereignty and not only to territorialized sovereignty; and there is a need for thinking of existing political communities, including the territorialized ones, to overcome the limitations of the multitude. Therefore, I propose a reformulation of the conceptualization of what I call here "complex sovereignty" which: 1) cannot be reduced to nation-state vs. global; 2) is not referable only to forms of domination but also of resistance, and 3) conceptually is based on the development of three notions: scales, interdependence and intersectionality. The idea is to recover and emphasize the relevance of the demos or political community in the process of redefining sovereignty. David Chandler (2009b: p. 544) expresses his concern that the globalization of politics reflects the abstraction and idealization of political engagement, increasingly less socially grounded: “when we engage 'globally' we engage with less social connection, with less social mediation, making our actions less strategic or instrumental, less clearly goal-orientated". My intention is to avoid abstraction and recover such an engagement by highlighting, among others, the importance of space (its uses, appropriations and connections) to reshape sovereignty.

\subsection{Multi-Scalar Sovereignty}

Hardt and Negri (2019: p. 73) explain that Empire is not a global state with a unified centralized structure of rule, and a homogeneous and unified political subject cannot be expected (something like "the global people"). Thus, globalization is both "processes of homogenization and heterogenization. Rather than creating one smooth space, the emergence of Empire involves the proliferation of borders and hierarchies at every geographical scale, from the space of the single metropolis to that of the great continents". The combination of processes of homogenization and heterogenization at every geographical scale is determinant, in my view, of a complex approach to sovereignty through the incorporation of scale. Hardt and Negri are right to single out these processes on the side of do- 
mination, but resistance can also be added (and both in relation to sovereignty as two-sided). The proliferation of borders and hierarchies stresses the spatial read of Empire. Borders are mainly deployed to nation-states (even as proof of their eroding sovereignty) but to other spaces too. The challenge is how to act within and against these spaces when the option suggested by Hardt and Negri (organizing the existing forms of production and reproduction) works quite limited.

Sovereignty is not vanishing but moving through scales to other spaces.

The terrain of nation-state is too easily disregarded by Hardt and Negri, although they have a point when stressing the insufficiency of returning to the state as the only option. Global capitalism and global governance raise many questions (from the transformation of the model of production to the internationalization of climate policies and their resistance) that barely can be satisfied from the perspective of nation-state. I consider that the starting point of Empire is quite valid: The form of Empire (neoliberal globalization, global governance) should be contested by the counter-Empire. However, the incarnation of that resistance by multitude presents two problems: The tendency towards abstraction (multitude existing at the global level) and the normative consideration of what counter-Empire is or what it is not (basically, everything that is not multitude does not count as counter-Empire). If Empire manifests itself at every geographical scale, the counter-Empire would do the same and in various forms, not limited to the form of multitude. The social and political struggles are, besides, struggles for sovereignty, but not every struggle is for global sovereignty. The conceptions of sovereignty (and of the political communities) at stake change through scales. Scales in themselves do not have democratic content (the local is not more democratic than the national, in principle). They are, as Mark Purcell (2006: p. 1921) recalls, "socially constructed strategies to achieve particular ends". The idea of multi-scalar sovereignty consists of exploring the struggles for sovereignty at different scales and their capacity (or not) of interconnecting scales.

The articulation of the $99 \%$ vs. the $1 \%$ is a clear example of how socio-spatialized struggles like the Occupy Wall Street movement at the urban scale is capable of scaling-up and envisioning a global antagonism between "ordinary people" and the elite. This is not just an abstraction, since the universalizing character of "the people" here is rooted in local struggles. Even a dramatic case like the Greek bailout referendum in 2015 makes different types of sovereignty visible: from popular sovereignty (manifested through the referendum) and state sovereignty (represented by the Greek government) to the international intervention by the European Union and the articulation of the national and transnational progressive movements supporting the $O x i$. It is difficult not to consider that these movements are activating notions of popular sovereignty at different scales and questioning the global capital and governance as well as national and local scales of command. That is the case of the Refugees Welcome solidarity movement when movements enhance practices of local solidarity and scale-up their de- 
mands at the national and European scales. The formation of municipal networks of solidarity within Europe proved how solidarity can become part of institutions and combining different scales. It should be noted that in all these cases, the identification of the enemy (Empire, the elite) is not sufficient, but organization in a more or less formal way (from movements to institution) is necessary.

The idea of "shared sovereignty" shows that sovereignty, far from being gone, is in process of redefinition. Although it is used (Krasner, 2004) to explain the involvement of international actors in some domestic issue (with the expectation that international agreements improve domestic sovereignty), Xavier Domènech (2017) acknowledges the insufficiency of state sovereignty in times of globalization but affirms that sovereignty must be shared by nation-states and international actors as well regional and municipal authorities and actors. "Sharing sovereignty" from the perspective of political and social actors is, actually, a good way of approaching sovereignty at multiple scales and as a combination of political and social forces (not to forget that sovereignty is a relationship). The notion of interdependence can grasp the conceptualization of sovereignty as multi-scalar and conflictual relationship.

\subsection{Interdependence}

The multitude must constitute a new Prince as a democratic structure, according to Hardt and Negri. They are not interested in substituting one ruler for another if the structures of government remain the same. However, Assembly reflects a close approach to the ongoing political and social struggles, in a similar way to Declaration (2012) which drew on the cycle of social protest from 2011. This explains that Hardt and Negri (2017) consider three forms of governance, based on three strategies: exodus, antagonistic reformism and taking power. Exodus consists of prefigurative politics, antagonistic reformism is engaging with existing institutions and transforming them from within, and taking power is the hegemonic operation of transforming the whole society. The novelty of this typology is that Hardt and Negri see them as complementary rather than divergent. This can be surprising since strategies of autonomy (exodus) and hegemony coexist and the differentiation between immanence and transcendence is not deployed to prioritize one strategy over the other. The strategies of antagonistic reformism and hegemony bring Hardt and Negri's positions closer to those of, for instance, Laclau and Mouffe. The complementary relation between state and stateless spaces and actors is important to introduce the first notion of interdependence. Focusing on the case of antagonistic reformism (which is opposed to cooperative reformism) shows that it is reformist both within and against the state and it must have alliances within projects outside the state (e.g. political parties and social movements). Interdependence contains the duality of sovereignty, expressed by parties, within the dynamics of existing institutions, and their openness to social movements and civil society in general. The cases of movement-parties such 
as Podemos in Spain or Syriza in Greece show that tension accentuated when they are in government. The same principle can be applied to new municipalism. Despite the proximity attributed to local politics, the tensions within the electoral coalitions (including movements, activists and parties), the institutional logic and the relationship with other parties show the complexities of acting within and against.

Together with this notion connecting, so to say, the institutional and social (or constituted and popular sovereignty), interdependence is also valuable in referring to communities and issues beyond the state and the way in which states interact with social movements and other transnational actors. Daniel Innerarity (2012) explains that interdependency generates a shift from sovereignty as control to sovereignty as responsibility, since the state has to be responsible for global issues such as climate change or human rights. Antonio Negri and Cocco (2006) reflect on interdependence as a matter of sovereignty as two-sided and of global sovereignty and offer a convincing approach to interdependence based on the Latin American experience. Governing interdependence implies the openness of hybrid forms of governance between political parties and social movements and combining a national and international scope of governance. The latter is interesting if the regional processes of cooperation in Latin America in the decade of the 00s are considered. Besides ruling nationally, there was a sense of governing interdependence through strengthening regional politics and creating new organizations (UNASUR, ALBA, CELAC). The strong ideological content of some of these organizations and the fear of transcending nation-state sovereignty revealed some of the weaknesses of the regional process. In any case, it is an example of multi-scalar sovereignty (national and regional) from the governments' perspective, but also from the movements that use national institutions, albeit addressing global issues. Since there is no constitutional and institutional framework to address global issues, the political community claims for their demands with different strategies and at different scales.

\subsection{Intersectional Political Community}

Thinking of sovereignty as multi-scalar and the dual meaning of interdependence is helpful to understand the recent changes of sovereignty. This framework allows us to approach sovereignty from the perspective of the ruled and not only of the ruler. The issue of political community is quite complicated. As shown, the post-territorial political community (multitude) presents several deficiencies. On the other hand, the people, as political community, fits better with the attribution of rights and duties, an existing institutional and legal framework and forms of mediation. The problem is that the people face difficulties as category applicable to global dynamics. Although it is possible to talk about people at different scales, the composition of the political community changes. It is not the same to receive undocumented migrants who express a sense of (urban) citizenship and become part of the local political community, on the one hand, and 
their acceptance within the nation-state, at least from the view of the sovereign power, on the other. Attached to popular sovereignty, the people can expand the representation, the connection between parties and movements, participation, but what is questionable is how inclusive a category like "the people" is to include the existing plurality of struggles. Hardt and Negri are quite clear that people entail a unified political subject subjugated to the one who commands. I consider that this remark must be taken seriously. Although my understanding of political community is territorialized (not exclusively anchored in nation-state but through scales) instead of deterritorial (avoiding the risks of abstraction) like multitude, its multiplicity must be assured. Therefore, political community must be intersectional.

The idea of adding intersectionality appears in the later work of Hardt and Negri in order to correct the predominance of economic dominance in their concept of multitude in detriment of other types of domination. In order to become intersectional, Hardt and Negri (2019: p. 87) propose the formula C-M-C'. The shift from class to multitude is due to the expansion of capitalism (and labor and the production of value) from the factory to the whole society. The need to move from multitude to class prime originates in adding other struggles not only based on capital struggles. The return to class (as class prime) is one "from a unified political conception based on a single axis of domination, that determined by capital, to a multiplicity, which also engages patriarchy, white supremacy and other axes". The new version of class is not merely socio-economic: It includes different relations of domination and implies that a sort of internal articulation is necessary. The way in which these struggles are articulated maintaining their specificities is quite confusing due to the effort to preserve their immanence. The same problem was previously identified with respect to the mediation of post-territorial political communities.

A similar formula could be applied to other territorial political communities as "the people" in order to obtain an intersectional political community that responds to diverse cross-cutting structural asymmetries. Thus, migrant, feminist, LGBT+ struggles could be part of an inclusionary notion of "the people". The case of the German Seebrücke (Sea Bridge) movement is a good example of how a movement demands the European governments to resume rescue missions in the Mediterranean and to allow refugees the right to asylum and, at the same time, calls on municipal authorities to declare themselves a "safe harbor" (Schwiertz \& Keß, 2019). Interdependence works here between movements and institutions and at the connection of local, national and international scales. The resulting intersectional political community, like the people, does not need to be grounded in humanitarian values but can reflect the multiplicity of forms of dominations such as race and class. One of the activists, Alina Lyapina (2019), emphasizes the commonalities despite multiple discriminations and enhances a community to claim for equal rights: "The people you call foreigners face the same daily problems you face. What unites you is the common struggle against those injustices 
you are both experiencing. We need to address the structural problems in the current political and economic set-up. A good life for everyone is possible no matter what the racist far right or those who actually cause those injustices tell you".

In all, intersectional political community articulates multiple discriminations and highlights the interdependence between movement and institutions while connecting and reframing rights and struggles which are (re)territorialized at different scales. It is possible to overcome then the limitations of the post-territorial political community and reflect the notion of "complex sovereignty" when the articulation scales and interdependence are constituting a new form of sovereignty, no longer reduced to nation-states or disappeared in the non-spaces of globalization.

\section{Conclusion}

The intellectual project initiated by Hardt and Negri twenty years ago offers an original and challenging way of conceiving sovereignty from its state to its global form. One of their most stimulating contributions is to think about the consequences of this emergent form of sovereignty, not least in relation to the political subject of resistance. However, at some point Hardt and Negri seem to reject the notion of sovereignty rather than redefining it. I have identified some of the problems related to Imperial sovereignty and the overcoming of state sovereignty proposed by Hardt and Negri and to the concept of multitude as the post-territorial political community of resistance against Empire. Through revising and reframing some of Hardt and Negri's contributions, I have elaborated an alternative framework to account for complex sovereignty, based on two ideas: The new form of sovereignty is rearticulating the connection between scales (global, national, local), rather than replacing the nation-state with the global, and sovereignty is dual, meaning the conflictual coexistence between those who command and those who are ruled. This dynamic conceptualization of complex sovereignty relies on three elements: multi-scalar sovereignty, interdependence and intersectional political community.

- Multi-scalar sovereignty. Rather than disappeared from nation-state, sovereignty has moved to different scales from global to national and local scales. None of these scales are autonomous (there is no such thing as full sovereignty at one sole scale) but rather interconnected. However, the connection between scales is not automatic so the challenge, especially from the perspective of resistance, is how to interconnect them and put every scale into value. It means that the local space is an important space to forge social and political alternatives as forms of popular sovereignty; the nation-state is still determinant to promote political change; and the global scale should be addressed to respond to the economic, political, environmental and social issues which go beyond the framework of nation-states.

- Interdependence: It should be consequently insufficient to think of nation-states 
as independent units of decision making within the global context as well as to consider governments as the only ones to make those decisions within the nation-states. This situation creates two spaces for interdependence: one between governments and civil society and another one between different nation-states or regions. The former requires complementing forms of representative politics with others of deliberation and participation whilst the latter implies increasing regional cooperation and integration by acknowledging their potential to address a common and globalized agenda. Both dimensions of interdependence entail different types of tensions: on the one hand, between political parties (or institutions) and social movements, and on the other, between national sovereignty and other forms of shared sovereignty.

- Intersectional political community. When thinking of political community, territorialized political communities such as "the people" have been criticized for reducing the plurality of society and paving the way for the appropriation of the "collective will" by a political leader. Multitude, as post-territorial political community, highlights the multiplicity of social struggles but lacks a clear way of organizing politically a community with its respective rights and duties. It is necessary to move beyond the opposition between unity and multiplicity and between territoriality and non-territoriality, and search for an intersectional political community which includes the plurality of identities and subjectivities and is capable of giving rights and recognitions to their members at different scales.

Thus, the risk of abstraction is corrected through the inclusion of scales but also the risk of limiting sovereignty to the nation-state. Interdependence is a concept applied to the relationship between movements and parties (or civil society and institutions) and the relationship between states, social movements and transnational actors at the international scales. Finally, considering the political community as intersectional adds plurality to the political subject and better grasps the diversity of responses to the multiplicity of dominances but within the articulation of a common political subject. Thus, I believe that this framework contributes to deepening the discussion of sovereignty and its challenges in times of globalization and enriches the debate that Hardt and Negri initiated with Empire and, fortunately, have maintained open since then.

\section{Conflicts of Interest}

The author declares no conflicts of interest regarding the publication of this paper.

\section{References}

Ali, M. (2020). Education and the Formation of the Multitude. In M. Jal, \& J. Bawane (Eds.), Theory and Praxis: Reflections on the Colonization of Knowledge (pp. 228-239). London: Taylor \& Francis. https://doi.org/10.4324/9780367809508-18

Amin, S. (2005). Empire and Multitude. Monthly Review, 57, 1-12.

https://doi.org/10.14452/MR-057-06-2005-10 1 
Amin, S. (2014). Contra Hardt and Negri: Multitude or Generalized Proletarianization? Monthly Review, 66, 25-36. https://doi.org/10.14452/MR-066-06-2014-10 2

Ashley, R. K. (1987). “The” Geopolitics of Geopolitical Space: Toward a Critical Social Theory of International Polities. Alternatives, 12, 403-434. https://doi.org/10.1177/030437548701200401

Attila, A. (2019). The Populism of the Empire and the Multitude. The Romanian Journal of Society and Politics, 13, 34-51.

Baiocchi, G. (2018). We, the Sovereign. Cambridge, MA: Polity Press.

Boron, A. (2005). Empire and Imperialism: A Critical Reading of Michael Hardt and Antonio Negri. London: Zed Books.

Brennan, T. (2003). The Empire's New Clothes. Critical Inquiry, 29, 337-367.

https://doi.org/10.1086/374030

Brown, W. (2010). Walled States, Waning Sovereignty. New York: Zone Books. https://doi.org/10.2307/j.ctv14gpj55

Brown, W. (2015). Undoing the Demos: Neoliberalism's Stealth Revolution. New York: Zone Books. https://doi.org/10.2307/j.ctt17kk9p8

Browning, G. K. (2005). A Globalist Ideology of Post-Marxism? Hardt and Negri's Empire. Critical Review of International Social and Political Philosophy, 8, 193-208. https://doi.org/10.1080/13698230500108876

Celikates, R., \& Jansen, Y. (2012). Reclaiming Democracy. An Interview with Wendy Brown on Occupy, Sovereignty and Secularism. Krisis, 3, 68-77.

Chandler, D. (2006). Empire in Denial: The Politics of State Building. London: Pluto Press.

Chandler, D. (2009a). Critiquing Liberal Cosmopolitanism? The Limits of the Biopolitical Approach. International Political Sociology, 3, 53-70. https://doi.org/10.1111/j.1749-5687.2008.00063.x

Chandler, D. (2009b). The Global Ideology: Rethinking the Politics of the "Global Turn" in IR. International Relations, 23, 530-547. https://doi.org/10.1177/0047117809350989

Cremin, C., \& Roberts, J. M. (2011). Postmodern Left-Liberalism: Hardt and Negri and the Disavowal of Critique. Critical Sociology, 37, 179-197. https://doi.org/10.1177/0896920510379442

Çubukçu, A. (2005). Multitude: War and Democracy in the Age of Empire by Michael Hardt and Antonio Negri. The Arab Studies Journal, 13-14, 168-173.

Domènech, X. (2017). Catalunya y España: Las soberanías y el estado plurinacional. In A. Domínguez (Ed.), Repensar la España plurinacional (pp. 39-57). Barcelona: Icaria.

Fotopoulos, T., \& Gezerlis, A. (2002). Hardt and Negri’s Empire: A New Communist Manifesto or a Reformist Welcome to Neoliberal Globalisation? Democracy \& Nature, 8, 319-330. https://doi.org/10.1080/10855660220148633

Gago, V. (2006). La multitud es ambivalente: Es solidaria y agresiva. Página 12. https://www.pagina12.com.ar/diario/dialogos/21-73518-2006-09-25.html

Hardt, M. (undated). Globalization and Democracy. https://globalization.mcmaster.ca/research/publications/working-papers/2001/ighc-wp s 01-1 hardt.pdf

Hardt, M., \& Negri, A. (2000). Empire. Cambridge, MA: Harvard University Press. https://doi.org/10.2307/j.ctvjnrw54

Hardt, M., \& Negri, A. (2004). Multitude. London: Hamish Hamilton.

Hardt, M., \& Negri, A. (2009). Commonwealth. Cumberland: Belknap Press. https://doi.org/10.2307/j.ctvjsf48h 
Hardt, M., \& Negri, A. (2017). Assembly. New York: Oxford University Press.

Hardt, M., \& Negri, A. (2019). Empire, Twenty Years On. New Left Review, 120, 67-92.

Harvey, D., Hardt, M., \& Negri, A. (2009). Commonwealth: An Exchange. Artforum, 48, 210-221.

Innerarity, D. (2012). La gobernanza global, de la soberanía a la responsabilidad. Revista CIDOB d'Afers Internacionals, 100, 11-24.

Kallis, A. (2018). Populism, Sovereigntism, and the Unlikely Re-Emergence of the Territorial Nation-State. Fudan Journal of the Humanities and Social Sciences, 11, 285-302. https://doi.org/10.1007/s40647-018-0233-Z

Krasner, S. D. (2004). The Hole in the Whole: Sovereignty, Shared Sovereignty, and International Law. Michigan Journal of International Law, 25, 1075-1101.

Lyapina, A. (2019). To Us, There Are No Migrants... There Are People. https://www.ohchr.org/EN/NewsEvents/Pages/StandingUpForMigrantsRights.aspx

Moore, M. J. (2011). Immanence, Pluralism, and Politics. Theory in Action, 4, 1-25. https://doi.org/10.3798/tia.1937-0237.11020

Negri, A., \& Cocco, G. (2006). Global: Biopoder y luchas en una América Latina globalizada. Buenos Aires: Paidós.

Purcell, M. (2006). Urban Democracy and the Local Trap. Urban Studies, 43, 1921-1941. https://doi.org/10.1080/00420980600897826

Schwiertz, H., \& Keß, F. (2019). Safe Harbours: The Cities Defying the EU to Welcome Migrants. Open Democracy. https://www.opendemocracy.net/en/safe-harbours-cities-defying-eu-welcome-migrant s

Shibasaki, A. (2019). A Conversation with Antonio Negri: Empire before and after, Multitude, Passion and Emotion, Bob Dylan and Michael Moore, and More. Global Europe-Basel Papers on Europe in a Global Perspective, 118.

Thompson, P. (2005). Foundation and Empire: A Critique of Hardt and Negri. Capital \& Class, 29, 73-98. https://doi.org/10.1177/030981680508600105

Virno, P. (2004). A Grammar of the Multitude. For an Analysis of Contemporary Forms of Life. Los Angeles: Semiotext(e).

Žižek, S. (2001). Have Michael Hardt and Antonio Negri Rewritten the Communist Manifesto for the Twenty-First Century? Rethinking Marxism, 13, 190-198.

https://doi.org/10.1080/089356901101241875 